\title{
Multi-drug Treatment for COVID-19-induced Acute Respiratory Distress Syndrome
}

\author{
COVID-19 Kaynaklı Akut Solunum Sıkıntısı Sendromu için Çoklu Illaç
} Tedavisi

\author{
(D) Masashi OHE* \\ Jcho Hokkaido Hospital, Clinic of Internal Medicine, Sapporo, Japan
}

\begin{abstract}
Coronavirus disease-2019 (COVID-19), caused by severe acute respiratory syndrome-coronavirus-2 (SARS-CoV-2), broke out in late 2019 to become a serious global threat to human health. In the absence of specific treatments for COVID-19, treatment options are being examined. Recently, the anti-SARS-CoV-2 activities of tetracyclines, macrolide antibiotics, and ivermectin (IVM), have attracted considerable attention for their potential as a single or multi-drug treatment regimen. Moreover, tetracyclines, macrolide antibiotics, and IVM possess anti-inflammatory and immunomodulatory effects to reduce the production of cytokines. COVID-19 is characterized by early exponential viral replication, cytokine storm-associated organ damage, including acute respiratory distress syndrome (ARDS) and thrombosis. Considering anti-inflammatory and immunomodulatory effects of the aforementioned drugs and corticosteroids, early treatment with doxycycline, azithromycin, IVM, and corticosteroids is thought to be the most promising option for combating COVID-19-induced ARDS.
\end{abstract}

Key words: COVID-19, doxycycline, azithromycin, ivermectin, corticosteroid

ÖZ

Şiddetli akut solunum yolu sendromu-koronavirüs-2'nin (SARS-CoV-2) neden olduğu Koronavirüs hastalığı-2019 (COVID-19), 2019'un sonlarında patlak vererek insan sağlığı için ciddi bir küresel tehdit haline gelmiştir. COVID-19 için spesifik tedavilerin yokluğunda tedavi seçenekleri inceleniyor. Son zamanlarda, tetrasiklinlerin, makrolid antibiyotiklerin ve ivermektinin (IVM) anti-SARS-CoV-2 aktiviteleri, tek veya çoklu ilaç tedavi rejimi olarak potansiyelleri nedeniyle büyük ilgi görmüștür. Dahası, tetrasiklinler, makrolid antibiyotikler ve IVM sitokin üretimini azaltmak için anti-inflamatuar ve immünomodülatör etkilere sahiptir. COVID-19, erken üstel viral replikasyon, akut solunum sıkıntısı sendromu (ARDS) ve tromboz dahil sitokin fırtınası ile ilişkili organ hasarı ile karakterizedir. Bahsi geçen ilaçların ve kortikosteroidlerin antiinflamatuar ve immünomodülatör etkileri göz önüne alındığında, doksisiklin, azitromisin, IVMve kortikosteroidlerle erken tedavinin, COVID-19 kaynaklı ARDS ile mücadelede en umut verici seçenek olduğu düşünülmektedir.

Anahtar kelimeler: COVID-19, doksisiklin, azitromisin, ivermektin, kortikosteroid

\section{INTRODUCTION}

Coronavirus disease-2019 (COVID-19), caused by severe acute respiratory syndrome-coronavirus-2 (SARS-CoV-2), broke out in late 2019 to become a serious global threat to human health. In the absence of specific treatments for COVID-19, treatment options are being examined. Recently, the anti-SARS-CoV-2 activities of tetracyclines [e.g., doxycycline (DOX)], macrolide antibiotics [e.g., azithromycin (AZM), and clarithromycin
(CAM)], and macrolide antiparasitic [e.g., ivermectin (IVM)], have attracted considerable attention for their potential as a single or multi-drug treatment regimen.

Apart from anti-SARS-CoV-2 activities, DOX, AZM, and IVM possess anti-inflammatory and immunomodulatory effects to reduce the production of interleukin-6 (IL-6), IL-8, and tumor necrosis factor- $\alpha$ (TNF- $\alpha$ ); IL-1, IL-6, IL-8, and TNF- $\alpha$; and IL-1, IL-6, and TNF- $\alpha$, respectively. ${ }^{1-3}$ 
In single-drug treatment studies in COVID-19, DOX, ${ }^{4} \mathrm{CAM},{ }^{5}$ and IVM $^{6}$ have proven effective against COVID-19.

In multi-drug treatment studies, Alam et al. ${ }^{7}$ found that a combination of IVM and DOX was effective for viral clearance in patients with mild and moderate COVID-19. Prasad ${ }^{8}$ reported on a patient where COVID-19 accompanied by pulmonary lesion was successfully treated with the early administration of IVM (6 $\mathrm{mg}$ twice daily for 3 days), AZM (500 mg daily for 5 days), DOX (100 mg twice daily for 5 days), and prednisolone (50 mg daily for 5 days) followed by dexamethasone (6 mg daily).

The primary purpose of the aforementioned drug treatments is to improve mild and moderate COVID-19 cases and prevent them from further deteriorating into the severe, life-threatening stage. Severe COVID-19 involves cytokine storm-associated organ damage, including acute respiratory distress syndrome (ARDS). Elevated blood levels of IL-6, IL-8, IL-10, and TNF- $\alpha$ were noted in COVID-19-induced ARDS, ${ }^{9}$ which was effectively treated with cytokine storm suppression, either using IL-6 inhibitor tocilizumab (TCZ) $)^{10}$ or a combination of TCZ and IVM."

Corticosteroids known to reduce the production of IL-6, IL-8, IL-10, and TNF- $\alpha,{ }^{12}$ were also found to reduce mortality in the patients with COVID-19-induced-ARDS and non-COVID-19induced ARDS. ${ }^{13}$

Tetracycline treatment within a year before ARDS diagnosis was associated with $75 \%$ reduced likelihood for mechanical ventilation during a hospital stay. ${ }^{14}$ Furthermore, tetracycline treatment corresponded to significant reductions in the length of mechanical ventilation use and intensive care unit stay in patients with ARDS.14 Although this study was conducted in patients with non-COVID-19, these results suggest that tetracycline is effective for COVID-19-induced ARDS. Additionally, treatment with macrolide antibiotics has also been associated with reduced mortality in ARDS. ${ }^{15}$

Multi-drug treatment is thought to be more effective than single-drug treatment because of the synergistic effect of the different mechanisms of action of the component drugs. ${ }^{16}$

Taken together, from a medical economic standpoint, early treatment with IVM, DOX, AZM, and corticosteroids may be the most promising option for combating COVID-19-induced ARDS.

However, clinical trials need to be conducted to better assess the optimal doses and durations for these medications as well as the efficacy and tolerability of this treatment before it can be implemented on a wider scale.

Conflict of interest: No conflict of interest was declared by the author. The author is solely responsible for the content and writing of this paper.

\section{REFERENCES}

1. Bernardino AL, Kaushal D, Philipp MT. The antibiotics doxycycline and minocycline inhibit the inflammatory responses to the Lyme disease spirochete Borrelia burgdorferi. J Infect Dis. 2009;199:1379-1388.
2. Zimmermann P, Ziesenitz VC, Curtis N, Ritz N. The Immunomodulatory effects of macrolides-a systematic review of the underlying mechanisms. Front Immunol. 2018;9:302.

3. Zhang X, Song Y, Ci X, An N, Ju Y, Li H, Wang X, Han C, Cui J, Deng X. Ivermectin inhibits LPS-induced production of inflammatory cytokines and improves LPS-induced survival in mice. Inflamm Res. 2008;57:524529.

4. Gironi LC, Damiani G, Zavattaro E, Pacifico A, Santus P, Pigatto PDM, Cremona O, Savoia P. Tetracyclines in COVID-19 patients quarantined at home: literature evidence supporting real-world data from a multicenter observational study targeting inflammatory and infectious dermatoses. Dermatol Ther. 2021;34:e14694.

5. Tsiakos K, Tsakiris A, Tsibris G, Voutsinas $P$, Panagopoulos $P$, Kosmidou M, Petrakis V, Gravvani A, Gkavogianni T, Klouras E, Katrini K, Koufargyris P, Rapti I, Karageorgos A, Vrenzos E, Damoulari C, Zarkada V, Sidiropoulou C, Artemi S, loannidis A, Papapostolou A, Michelakis E, Georgiopoulou M, Myrodia DM, Tsiamalos P, Syrigos K, Chrysos G, Nitsotolis T, Milionis H, Poulakou G, Giamarellos-Bourboulis EJ. Oral clarithromycin in COVID-19 of moderate severity: the ACHIEVE open label trial using concurrent matched comparators medRxiv. doi: 10.1101/2020.12.22.20248753.

6. Ahmed S, Karim MM, Ross AG, Hossain MS, Clemens JD, Sumiya MK, Phru CS, Rahman M, Zaman K, Somani J, Yasmin R, Hasnat MA, Kabir A, Aziz AB, Khan WA. A five-day course of ivermectin for the treatment of COVID-19 may reduce the duration of illness. Int $\mathrm{J}$ Infect Dis. 2021;103:214-216.

7. Alam MT, Murshed R, Bhiuyan E, Saber S, Alam RF, Robin RC. A case series of 100 COVID-19 positive patients treated with combination of ivermectin and doxycycline. Bangladesh Coll Phys Surg. 2020;38(Supplement Issue):10-15.

8. Prasad A. Early administration of ivermectin, azithromycin \& doxycycline along with i.v. prednisolone in a case of COVID -19 disease may lead to early recovery? Int J Pharm Chem Anal. 2020;7:149-150.

9. Wang J, Yang X, Li Y, Huang JA, Jiang J, Su N. Specific cytokines in the inflammatory cytokine storm of patients with COVID-19-associated acute respiratory distress syndrome and extrapulmonary multipleorgan dysfunction. Virol J. 2021;18:117.

10. Menzella F, Fontana M, Salvarani C, Massari M, Ruggiero P, Scelfo C, Barbieri C, Castagnetti C, Catellani C, Gibellini G, Falco F, Ghidoni G, Livrieri F, Montanari G, Casalini E, Piro R, Mancuso P, Ghidorsi L, Facciolongo N. Efficacy of tocilizumab in patients with COVID-19 ARDS undergoing noninvasive ventilation. Crit Care. 2020;24:589.

11. Chuang TY, Tsai MH, Wu LM, Ho SJ, Yeh PS, Liu YL, Fred Yang HJ. Successful treatment of tocilizumab and ivermectin for a patient with ARDS due to COVID-19. J Microbiol Immunol Infect. 2020;54:147-148.

12. Giamarellos-Bourboulis EJ, Dimopoulou I, Kotanidou A, Livaditi O, Pelekanou A, Tsagarakis S, Armaganidis A, Orfanos SE. Ex-vivo effect of dexamethasone on cytokine production from whole blood of septic patients: correlation with disease severity. Cytokine. 2010;49:89-94.

13. Chaudhuri D, Sasaki K, Karkar A, Sharif S, Lewis K, Mammen MJ, Alexander P, Ye Z, Lozano LEC, Munch MW, Perner A, Du B, Mbuagbaw L, Alhazzani W, Pastores SM, Marshall J, Lamontagne F, Annane D, Meduri GU, Rochwerg B. Corticosteroids in COVID-19 and nonCOVID-19 ARDS: a systematic review and meta-analysis. Intensive Care Med. 2021;47:521-537. 
14. Byrne JD, Shakur R, Collins JE, Becker S, Young CC, Boyce H, Traverso G. Prophylaxis with tetracyclines in ARDS: Potential therapy for COVID19-induced ARDS? medRxiv. doi: 10.1101/2020.07.22.20154542.

15. Simonis FD, de ludicibus G, Cremer OL, Ong DSY, van der Poll T, Bos LD, Schultz MJ; MARS consortium. Macrolide therapy is associated with reduced mortality in acute respiratory distress syndrome (ARDS) patients. Ann Transl Med. 2018;6:24.

16. Ohe M, Furuya K, Goudarzi H. Multidrug treatment for COVID-19. Drug Discov Ther. 2021;15:39-41. 